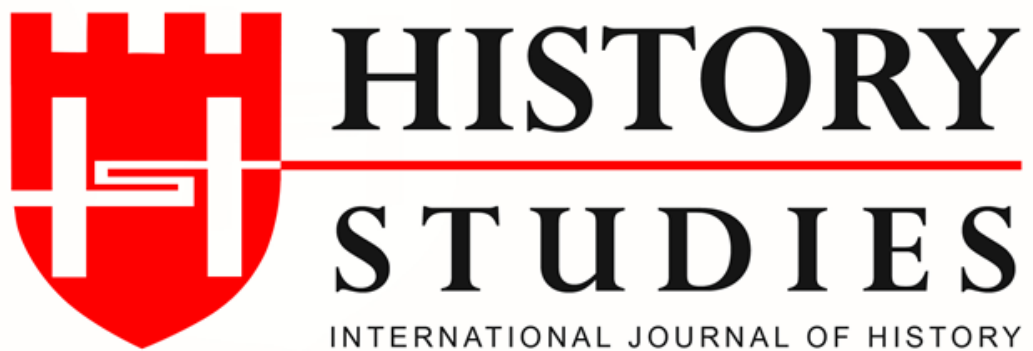

ISSN: 13094173 / (Online) 1309 - 4688 (Print)

Volume: 13, Issue: 5, October 2021

www.historystudies.net

HISTORICAL JOURNEY OF THE TERM OF UNIONISM: THE COMMITTEE OF UNION AND PROGRESS IN THE TRIANGLE OF PERCEPTION, PRECONCEPTION AND METHOD

İttihatçılığın Tarihsel Serüveni:

Algılar, Yargllar ve Yöntem Ü̧̧geninde İttihat ve Terakki

Arş. Gör. Burak Aslanmirza

Kocaeli Üniversitesi

burakaslanmirza@gmail.com

ORCID ID: ORCID: 0000-0003-0509-5435

Makale Türü-Article Type Geliş Tarihi-Received Date Kabul Tarihi-Accepted Date DOI Number
Araştırma Makalesi-Research Article 03.05.2021

04.09.2021

10.9737/hist.2021.1043

Atıf-Citation: $\quad$ Burak Aslanmirza, “Historical Journey of the Term of Unionism: The Committee of Union and Progress in the Triangle of Perception, Preconception and Method", History Studies, 13/5, Ekim 2021, s. 1475- 

HISTORY STUDIES

Uluslararası Tarih Araştırmaları Dergisi International Journal of History

13/5, Ekim - October 2021

1475-1498

Araştırma Makalesi

\section{HISTORICAL JOURNEY OF THE TERM OF UNIONISM: THE COMMITTEE OF UNION AND PROGRESS IN THE TRIANGLE OF PERCEPTION, PRECONCEPTION AND METHOD}

İttihatçılığın Tarihsel Serüveni: Algılar, Yargılar ve Yöntem Üçgeninde İttihat ve Terakki

\section{Arş. Gör. Burak Aslanmirza}

\section{$\ddot{O} z$}

İttihat ve Terakki Cemiyeti 1889'da ortaya çıkışından Mütareke devrinin sonuna değin geçen zaman zarfinda "cemiyet-i fesadiyye"den "cemiyet-i mukaddese"ye ve sonra tekra "cemiyet-i fesadiyye"ye bir dönüsüm yaşamıștır. Birtakım eski İttihatçıların Milli Mücadele ve erken Cumhuriyet devirlerinde oynadıkları rol, İttihatçılık algılarının Cumhuriyet devri siyasal argümanlarına da taşınmasına kaynaklık etmiștir. 1926 İzmir Suikast Teşebbüsü ile İttihatçıların aktif siyasi hayatı sona ermiş olsa da, İttihatçılık algıları, sosyal politik ve ideolojik araçlar halinde, İttihat ve Terakki üzerine yapılan çalışmalarda söz konusu edilen argümanların bir parçası olarak orijininden neredeyse hiç sapmadan varlığını sürdürmüștür. Geçen süre zarfinda, eski İttihatçılık algıları, Türkiye'nin güncel kaygı ve önceliklerine göre belirginleșen yeni kavramsal yaklaşımlarla zenginleşmiş, fakat II. Meşrutiyet devrinde İttihat ve Terakki'yi meşrulaştırma ve gayri meşrulaştırma maksatlı aşırılaştırılmış siyasal argümanlar etrafinda belirginleșen İttihatçılık algıları, bugüne kadar çok az değişime uğrayarak devamlılıkların korumușlardır. $\mathrm{Bu}$ devamlılık, bir yandan II. Meșrutiyet devri siyasal gelişmelerini Cumhuriyet Türkiye'sinden geriye doğru anlama çabasını bir yöntem haline getirmiş ve bir yandan da II Meşrutiyet devrinde şekillenen İttihatçılık algılarından kaynaklı argümanlarını da pekiştirerek İttihat ve Terakki çalışmalarındaki ön yargı ve yaygın kabullerin şekillenmesine etkide bulunmuştur. Dolayısıyla, İttihat ve Terakki çalışmalarının gelecek seyri açısından, İttihat ve Terakki tarih yazımının rasyonel bağlamın tartışmak önemli görülmelidir.

Anahtar Kelimeler: İttihat ve Terakki Cemiyeti (ITC), İttihatçılık, II. Meşrutiyet, İttihatçılar, Tarih yazımı, Algı

\begin{abstract}
During the period from its emergence in 1889 until the end of the Armistice period, the Committee of Union and Progress (CUP) underwent a transformation from "the seditious committee (cemiyet-i fesadiyye)" to "the sacred committee (cemiyet-i mukaddese)", and then back to "seditious" one. The role played by some former Unionists during the National Struggle and the early Republican periods was the source of the transfer of the perceptions of Unionism to the political arguments in the Republican period. Although the active political life of the Unionists was terminated with the 1926 İzmir Assassination Attempt, the perceptions proceeded within the language shaping the studies on the CUP as socio-political and ideological tools, almost without deviating from their origin. Over the course of time, the old perceptions about Unionism have been enriched with new conceptual approaches that have been shaped by Turkey's current concerns and priorities; however, the perceptions about Unionism, which became apparent around excessive political arguments with the aim of legitimizing or illegitimating the CUP during the Second Constitutional era, have remained in existence as the result of having undergone very little change until today. This continuity, has, on the one hand, influenced the efforts to understand the political developments of the Constitutional era retrospectively from the Republic of Turkey, while, on the other hand, led to the formation of the prejudices and general acceptances in CUP studies by reinforcing the arguments stemming from the perceptions about Unionism during the Constitutional era. Thus, it is significant to reconsider the rational context of the CUP historiography in terms of the future course of CUP studies.

Keywords: Committee of Union and Progress (CUP), Unionism, Ottoman Constitutional Regime, Unionists, Historiography, Perception
\end{abstract}




\title{
Introduction
}

The Committee of Union and Progress (CUP) made its mark on Turkish political life through its critical role in the transition to parliamentary life. Thus, it has always been a point of attraction for researchers to be able to understand the core paradigms of Turkish political life. The origins of the developments in the Republican period were researched in the parliamentary life of the Second Constitutional period and the suggestion that there is a social, cultural, political, economic, and intellectual continuity between the two periods became more emphasized over time. However, offering new insight into the continuity and rupture paradigm today requires an examination of the political developments in the Second Constitutional period independently of the political arguments of the Republican period. After certain investigations on the characteristic features of the Second Constitutional period in its own internal dynamics, suggestions on the continuity, rupture, change, and transformation matters should be rediscussed in a prospective manner.

Arguments developed regarding the CUP, which was the most dominant actor in the political life of the Second Constitutional period, have mostly been the products of a retrospective view, which means an effort to understand it from the Republican period backwards. The reason behind this should be sought on the fact that the perceptions about Unionism that emerged in the period, where the Unionists were active in the politics, and their arguments regarding Unionism have remained in existence even after the Unionists. The perceptions of "sacredness (kutsiyet)" that the Unionists attributed to themselves and its direct opposite "sedition (fesatllk)" were beyond being the key elements of the political rhetoric of the era, but they were the main motivational sources that shaped the political developments and arguments in the era. Therefore, the allegations and accusations evident through the sources of the era have caused some problems in understanding the rationality of the period. Moreover, the ideological approaches that emerged in the Republican period had to determine an attitude towards the Unionists, which resulted in the transmission of the irrational political arguments by enriching them with new concepts and approaches that emerged in line with the current political, cultural, social, and economic priorities and concerns of the Republican period. Thus, understanding the true existence of the CUP has become a new challenge for researchers who are studying it. This study proposed a different suggestion on the paradigm of the continuity envisaged between the Second Constitutional and the early Republican periods with regards to the perceptions about Unionism. In this study, the perceptual type of continuity was considered not only as a determination, but also as a source of the other methodological problems in CUP studies.

This study had three objectives. First, it aimed to describe the characteristics of the perceptions about Unionism in the Republican period by focusing on the perceptions of Unionism in the period in which the Unionists involved in the political life and their sources. Secondly, it sought an answer to the question of how the perceptions about Unionism continued in the Republican period by examining the ongoing relationship between the former perceptions about Unionism and CUP studies throughout the prevailing literature. Third, it examined the relationship between the perceptional continuity and methodological problems in the CUP historiography. All in all, the continuity assumed between the two periods can only be understood to a certain extent retrospectively, which means by associating the new concepts and approaches that shaped around the political concerns and priorities of the early Republican period with Second Constitutional political life. However, prospectively examining the continuity arguments, in other words, after the assessment and interpretation of the internal dynamics of the Second Constitutional period, following a chronological order to examine the continuity and the changes, will enable the attainment of stronger grounded results for the historiography. Once this has been accomplished, it will be possible to ground the reciprocal interaction between the two periods with their special

\author{
History Studies \\ www.historystudies.net
}


semantic equivalents, and distinguish between the claims of the continuity, rupture, changes, and transformations.

\title{
1. Perceptional Origins of Unionism
}

\subsection{From the "Seditious Committee" to the "Sacred Committee"}

The source of the prominent opinions in CUP studies can be found in how the CUP and the Unionists defined themselves, and how their opponents politically reacted to the policies that the Unionists implemented between 1908 and 1918. The Unionists politically intimidated their political alternatives, and the Committee became intertwined with the state gradually, until its self-termination in 1918. The CUP used and highlighted its "sacredness" attributed by itself to ensure political legitimacy and nullify their opponents between 1908 and 1918. Beyond a rhetoric, the discourse of "sacredness" should be considered as the main component of the Unionist political dynamics, since it was the motivation that determined the Unionists' relationship with the state, and the other political institutions and organizations of the Constitutional regime. The reactionary attitudes against the CUP also emerged with equal extremism. Primary sources from the period carried the marks of the irrationalized political discourse of these extreme ends of the political spectrum. Furthermore, political continuity between the Constitutional and early Republican periods conveyed the same rhetoric without rationalizing the language of the sources to the 21st century. Thus, being able to follow the obvious subjectivism in studies on the CUP requires an understanding of what the "sacredness" that has been emphasized since 1908 really means.

Although the foundation of the CUP was based on a secret organization that was established in 1889, the actual milestone regarding the history of the Committee was in 1906. The activities of the Committee were mainly the result of personal efforts, and the nature of the movement was restricted in the intellectual dimension until 1906. The CUP acquired a centralized appearance as a result of the personal attempts of Dr. Bahaeddin Şakir Bey and Dr. Nazım Bey in Paris, in 1906. The nature of the Committee completely changed later with the merger of the Ottoman Freedom Committee, established in Salonica in the same year, and the Paris organization. The movement turned into a bureaucratic and armed rebellion in addition to its intellectual aspect, as on-duty military and civil officers in Macedonia started participating in the Committee in 1906. ${ }^{1}$ The state referred to the CUP as the "seditious committee (cemiyet-i fesadiyye)" and the Unionists as the "mischief-makers (erbab-1 fesad)" until the re-proclamation of the constitutional monarchy. ${ }^{2}$ After 1908, the CUP evolved into the "sacred committee (cemiyet-i mukaddese)" and the Unionists became the "the heroes of the freedom (kahraman-1 hürriyet)". ${ }^{3}$

\footnotetext{
${ }^{1}$ The founders of the Ottoman Freedom Committee were as follows: Bursalı Tahir Bey, Naki Bey (Yücekök), Edip Server Bey (Tör), Kazım Nami Bey (Duru), Ömer Naci Bey, İsmail Canbolat Bey, Hakkı Baha Bey, Mehmet Talat Bey, Rahmi Bey, and Mithat Şükrü Bey (Bleda). See Tarık Zafer Tunaya, Political Parties in Turkey, vol. I, (İstanbul: Hürriyet Vakfi Yurt Yayınları, 1988), 21-22. Additionally, because of the differences between the new organization founded with an altered name, called the Committee of Ottoman Progress and Union, as a result of the merger of the Unionist group in Paris and the Ottoman Freedom Committee centered in Thessaloniki, and the former organization, some researchers have proposed that the CUP after 1906 should be considered as a separate organization from the old one founded in 1989. See Suavi Aydın, "İki İttihat-Terakki: İki Ayrı Zihniyet, İki Ayrı Siyaset", Modern Türkiye'de Siyasi Düşünce: Cumhuriyet'e Devreden Düşünce Mirası, Tanzimat ve Meşrutiyet'in Birikimi (İstanbul: İletişim Yayınları, 2009), 117-128.

2 BOA (Devlet Arşivleri Başkanlığı Osmanlı Arşivi), Y..A...HUS. (Yıldız Hususi Maruzat), 503/107; BOA, ZB. (Zabtiye), 591/2.

${ }^{3}$ The period of the "Great Cabinet (Büyük Kabine)", founded in 1912, is an exception for the reflection of the CUP on documents. It can be seen in the documents of this period that old imputations of the Hamidian period attributed to the Committee could be used. BOA, DH.SYS (Dahiliye Siyasi Kısım), 65/8; BOA, DH.MUİ (Dahiliye Muhaberat-1 Umumiye İdaresi), 164/33.
}

\author{
History Studies \\ www.historystudies.net
}


After the re-proclamation of the constitutional regime, the Committee held the honor of the guardianship of the revolution. However, instead of taking the ruling power, the Unionists gave priority to increasing their power resources, reinforcing their political legitimacy, strengthening their organizational structure, and trying to increase the number of members by enlarging the organization throughout the Empire between 1908 and 1913. ${ }^{4}$ The Committee consolidated its self-attributed guardian role as a result of the suppression of the 31 March Rebellion by the Action Army (Hareket Ordusu), formed by the Unionists military officers, and the Committee continued to interfere with the politics, both externally and internally, by reinforcing its image of "the sacred committee." The government staff were immediately re-designed by the Unionists. The Committee obtained a major part of its ruling power through Unionist ministers in the cabinet, governors, deputies, military officers, bureaucrats, and civil servants, without directly taking the responsibility of being the party in power. ${ }^{6}$ In 1913, the CUP took complete power by the Raid on the Sublime Port (Bab-1 Ali Baskın1) and declared its structure, officially turning into a political party. The CUP succeeded in reducing the power of its political opponents by making use of the political conditions induced by the martial law (İdare-i Örfiye) and World War I, and effectively maintained its position in power without any interruption until its self-termination in 1918. The forerunner decisions of radical changes, such as the creation of national bourgeoisie, regulation of the authorities of the Bab-1 Meşihat (The Office of Grand Mufti), promulgation of the Law of Family Rights, and enforcements of Turkification, were made during this period.

The Unionists had reinforced their own political power by decreasing the visibility of other political movements in the public sphere gradually, between 1908 and 1918. By the intertwinement of the state and the Committee within 10 years, the Committee became not only the sole owner of political power, but also the entire public existence. Specifically, the Unionist clubs that rapidly spread in the provinces had a major role in this. A great number of Schools of Union and Progress established by the clubs, local press activities that they managed, and social and political activities that they organized in the peripheries played an important role in increasing both the number of members and the political visibility of the Committee. ${ }^{7}$ The many Union and Progress schools were taken into service in a short time across the Empire in different provinces such as Monastir, Bolvadin, Gaza, Thessaloniki, Haymana, Beirut, Ankara, Antalya, Alexandria, Konya, İzmir, Manisa, Mosul, Bursa, Trabzon, and İstanbul. ${ }^{8}$

\footnotetext{
${ }^{4}$ Feroz Ahmad, Ittihat ve Terakki 1908-1914, trans. Nuran Yavuz (İstanbul: Kaynak Yayınları, 2019), 221.

${ }^{5}$ The CUP strictly emphasized its connection with the army to reinforce its own legitimacy. The following emphatic statement of Bahaeddin Şakir is a good example reflecting this understanding: "The Committee is the protector of the country, the keeper of the freedom and the constitutional regime together with the army. The Committee is the picture of the nation and the army." Muhittin Birgen, Ittihat ve Terakki'de On Sene, ed. Zeki Arıkan (İstanbul: Kitap Yayınevi, 2017), 67.

${ }^{6}$ Tarık Zafer Tunaya, Türkiye'de Siyasal Partiler, Vol.III (İstanbul: Hürriyet Vakfı Yurt Yayınları, 1989), 29-30. Ahmad, Ittihat ve Terakki 1908-1914, 219. Sina Akşin described the period between 1908 and 1913 as the "supervisory rule of the Committee of Union and Progress" due to the political position of the CUP. Sina Akşin, Jön Türkler ve İttihat ve Terakki (İstanbul: İmge Kitabevi, 2017), 139-145.

${ }^{7}$ For detailed information about the activities of the Committee's clubs, see: Ali Çiftçi, "İttihat ve Terakki Cemiyeti'nin Örgütlenme ve Yönetim Yapısı İçinde Kulüplerin Yeri”, Selçuk Üniversitesi Türkiyat Araştırmaları Dergisi, no. 37 (2015): 115-141.

${ }^{8}$ The names and locations of some of these schools can be identified in the documents in the state archives. See BOA, MB.İ. (Mabeyn-i Hümayun Evrakı İradeleri), 143/89; BOA, MF.İBT. (Maarif Nezareti, Tedrisat-1 İbtidaiye Kalemi), 259/102; BOA, BEO (Bab-1 Ali Evrak Odas1), 3762/282126; BOA, BEO, 3782/283623; BOA, MF.IBT., 290/7; BOA, İ.MF (İrade Maarif), 17/10; BOA, DH.İD. (Dahiliye İdare), 26/23; BOA, MB.İ., 149/60; BOA, MB.İ., 153/104; BOA, MF.İBT., 377/75; BOA, MF.İBT., 455/45; BOA, MF.İBT., 455/10; BOA, DH.UMVM (Umur-1 Mahalliye ve Vilayat Müdürlüğ̈̈), 133/47; BOA, DH.UMVM, 67/19; BOA, DH.MB..HPS. (Dahiliye Hapishaneler Müdiriyeti), 13/37. For detailed technical information about the Schools of Union and Progress, see Hakan Aydin's study in the case of Konya: Hakan Aydın, Ittihat ve Terakki Mekteplerinin Yapısal Özellikleri Üzerine Bir Inceleme (PhD diss., Selçuk University, 2008), Konya.
}

\author{
History Studies \\ www.historystudies.net
}


Another superiority of the CUP regarding the development of its political influence over all other political institutions and organizations was based on the fact that they were able to use the state resources. Although the schools opened by the Union and Progress Clubs were actually considered private schools, unlike the other private schools in the Empire, they could benefit from the state's financial support. ${ }^{9}$ Moreover, the Committee announced its superior place in power, and even its embedded structure with the Palace to the public, by placing phrases of "freedom, equality, justice", which were sloganized by the CUP, around the sultan's signature (tuğra) on the coins minted, as the sign of Sultan Mehmet Reşat's reign/power in 1909. ${ }^{10}$ Furthermore, companies affiliated with the CUP and paramilitary organizations, and other institutions and organizations under the influence of the CUP, such as Donanma-yı Osmanî Muavenet-i Milliye Cemiyeti (Committee of Charity for the Ottoman Navy), Müdafaa-y1 Milliye Cemiyeti (The Committee of National Defense), and Hilal-i Ahmer (Turkish Red Crescent) had an important place in the expansion of the Unionists' political influence. ${ }^{11}$ Additionally, daily and unofficial contacts established by women faithful to the CUP were as important as other factors in the penetration of the political power of the CUP in the private sphere. ${ }^{12}$

The media was the most important tool used to arouse the interests of the people from different backgrounds and opinions, and strengthen their interest to the Committee. It was possible to understand from the statements of Muhittin Birgen, the editor-in-chief of Tanin during World War I, that newspapers and journals in relation to the Committee were "colorful" political manipulation tools, and they aimed to convey and impress on the decisions made by the Committee by using the different political languages of the different audiences for maintaining

\footnotetext{
${ }^{9}$ The fact that the Schools of Union and Progress were officially registered as private schools was understood from the response letter from the Ministry of Education to the petition of the Diyarbakır Provincial Directorate of Education: BOA, MF.MKT. (Dahiliye Nezareti Mektubi Kalemi), 1167/87/4. Buildings and lands in the Emlak-1 Humayun (Sultan's Estate) could be allocated to the use of the Committee for the Schools of Union and Progress. For example, the Müşir Osman Paşa Mansion (Sahilhane) was given to the CUP with a similar procedure. BOA, BEO, 3506/262887/1-2. Moreover, Some amount of land under the Ministry of Finance was allocated to the Thessaloniki School of Union and Progress with a government decree in the Meclis-i Vükela (Council of Grand Viziers and Ministers). BOA, İ..DFE. (İrade Defteri Hakani), 23/43/1, 2, 4.

${ }^{10}$ The same application was maintained in the coins minted on the name of Mehmet Vahdettin before the end of the Great War in 1918. For the examples of coins, see: Kaan Uslu \& Yavuz Büyüktuncay, ed., Osmanlı Imparatorluğu Madeni Paraları 1839-1922 (AH 1255-1340) (İstanbul: Osmanlı Nümismatik Kültür Yayınları, 2018), 120-121, 138. Osman Nuri Lermioğlu gave a place to this event in his criticisms about the CUP in his memoirs: "The words 'brotherhood, equality, justice', which later turned out to be the admirer of the Freemasons, were engraved on both sides of the re-minted and re-circulated coins around the place of the inscirptions and the sultan's signature. If it is necessary to tell the truth, from that day, we became impuissant against the freedom of which we only heard the name and the impunity of persons." Osman Nuri Lermioğlu, Halkın İstemediği İnkılap - Meşrutiyet, (İstanbul: Sabah Kültür Yayınları, 1976), 28.

${ }^{11}$ Tunaya, Türkiye'de Siyasal Partiler, Vol.III, 249-295; Erol Akcan, Ittihat ve Terakki Fırkası 'nın Paramiliter Gençlik Kuruluşları, (Ankara: Türk Tarih Kurumu Yayınları, 2015). In a British intelligence report dated October 1916, the connection of the companies established by the CUP with Turkish politics was emphasized and the external view of these companies were explained as in the following sentence: "'Millî' (National) became in the commercial world almost a synonym for 'C.U.P."” See: Zafer Toprak, Türkiye'de Milli İktisat 1908-1918 (İstanbul: Doğan Kitap, 2012), 681.

12 There are important hints about women's roles in the CUP's power structure in the memoirs of Naciye Neyyal Hanım. The de facto positions of Melika Hanım, the wife of Kazım Nami Bey (Duru), and especially Fatma Seniye Hanım within the organizational structure of the CUP are distinctive in the role of transfusion of power to private sphere. House visits and neighborhood relations had an important place in the power transfusion. The mediatory role of Fatma Seniye Hanım in the dialog between people outside the upper power circles and the executive cadre in the CUP due to her close relationships with the leading members of the CUP, such as Ragıb Bey, Kazım Nami Duru, and Ziya Gökalp was remarkable. Expanding its influence of power within circles towards the non-governing strata of society, especially through women, was indubitably among the factors that deepened and reinforced the political power of the CUP. Naciye Neyyal, Ressam Naciye Neyyal'in Mutlakiyet, Meşrutiyet ve Cumhuriyet Hatıraları, ed. Fatma Rezzan Hürmen, (İstanbul: Pınar Yayınları, 2000), especially 308-325.
}

\section{History Studies \\ www.historystudies.net}


and increasing public interest on the Committee. ${ }^{13}$ Decisions made in the Head Office (Merkez-i Umumi) of the Committee agitated to the public via these publications with different attitudes and tones, such as Íslam Mecmuasi, Milli Mecmua, Yeni Mecmua, and Tanin. ${ }^{14}$ The CUP even aimed to extend its influence to villages; hence, some separate local publications were prepared by some local offices and clubs for the villagers. ${ }^{15}$ Not only a wide range of periodicals but also the publications of many books and booklets enabled the consolidation of its power. In the booklet published by Hatibzade Mehmed Ayetullah, before the 1912 elections, with the name "Kime Rey Verelim? (Who to Vote?)", he compared the CUP and the Freedom and Entente Party objectively, in his own words, by the following statement at the end of the booklet: "The welfare of the nation depends on the power of the CUP and also the union of all Muslims. If the CUP falls, then the whole nation falls to pieces. And -God forbid- it may get ruined."16

The Committee used the image of the "sacredness" to transfigure itself among other political institutions and organizations starting in 1908, and managed to recruit many members until its self-termination in $1918 .{ }^{17}$ Unionism became so intertwined with the state that Unionism gained a sole appearance without any alternative in the economic, political, military, or social public spheres until the period of the Armistice. After the defeat of the Ottoman Empire in World War I

${ }^{13}$ It can be understood from the memoirs of Muhittin Birgen that the Head Office of the CUP regarded the circulations of the official and semi-official media organs of the Committee as a sort of public opinion poll to measure the people's political support and interest in itself: "Tanin, which I managed on behalf of the CUP, became an obscure newspaper at that time. With the prolongation of the War and the antipathy developed against the CUP due to the stories of corruption, which were partly true and partly false, and everyone's feeling the need of being rather thrifty, there was a decrease in the sales by 1000-1500 copies. I understood from the statements of some people that this was discussed in the Head Office at that time. Ziya Gökalp, who was trying to find a meaning and a color for the CUP with the Milli Местиа, advised me to 'add a color to this newspaper' one day. (...) Since the same advises were given to me with the same words by the members of the Head Office, such as Dr. Resuhi and Dr. Nazım in short intervals, I felt compelled to check myself." Birgen, Ittihat ve Terakki'de On Sene, 65-66.

${ }^{14}$ One of the reasons for including thinkers in the Head Office, which was the top governmental body of the CUP, should be seen as the need of theorizing the decisions that were made and enabling them to be propagated in appropriate frameworks. The roles of Hüseyin Cahit (Yalçın) and Ziya (Gökalp) in the Head Office had gained more importance over time, as the Committee felt the need to strengthen its social aspect more. Moreover, all of the press and broadcasting organizations associated with the Committee were managed by the Head Office. For the articles regulating the relations with the press in the 1916 Regulation, see: Osmanll Ittihad ve Terakki Cemiyeti Program ve Nizamnamesidir - 1332 Senesi Umumi Kongresinde Tadil ve Kabul Edilmiştir (İstanbul: Tanin Matbaası, 1332 [1916]), 13. For the 1913 Regulation, see: Tarı Zafer Tunaya, Türkiye'de Siyasal Partiler, vol.I, 110-112. The remarkable role that Ziya Gökalp assumed in the Committee is clearly revealed in the meetings of the Unionists in the upper ruling circle. See, BOA, HSDHADB (Satın Alınan Evrak Hacı Adil Bey Evrak1), 4/2/2/1, 4/2/2/5.

15 There are still a limited number of such journals that can be identified. The peasant newspaper Vatandaş, published by the Third Club of Thessaloniki, and the peasant journal Işılk, published by the İstanbul-Süleymaniye Club, which were studied by Arda Odabaş in two separate articles, can be given as examples. The following lines were included in the identity of "Vatandaş", which are also noteworthy in order to understand the propaganda methods of the CUP: "The patriot literates do read and explain the newspaper to the villagers." İ. Arda Odabaş, "Selanik İttihat ve Terakki Üçüncü Kulübü'nün Köylü / Köycü Gazetesi: Vatandaş”, Çağdaş Türkiye Tarihi Araştırmaları Dergisi 10, no.22 (2011): 50; Odabaş, "İttihat ve Terakki Cemiyeti Süleymaniye Kulübü'nün Anadolu Köylüsü İçin Çıkardığı Bir Yayın: Işık”, İstanbul Arel Üniversitesi İletişim Çalışmaları Dergisi 4, no.7 (2015): 13-31.

${ }^{16}$ Hatibzade Mehmet Ayetullah, Kime Rey Verelim? Ittihat ve Terakki - Hürriyet ve İtilaf Hangisi Iyi (İstanbul: Matbaa-yı Hayriye ve Şürekası, 1328 [1912]), 32.

${ }^{17}$ A group consisting of the exiles and fugitives of the Hamidian era, who felt that they were excluded by the CUP, despite their own efforts in the declaration of constitutional regime, came together under the umbrella of the Committee of Devotees of the Nation. Using the same political legitimization discourse and tools as the CUP and targeting the monopoly established by the CUP on the regime, the Devotees of the Nation soon drew the reaction of the Unionists. In the end, the Fedakeran-1 Millet Cemiyeti was closed on the grounds of the 31 March Incident. The CUP had clearly taken the title of revolutionism in its own hands, and never been aspired to share this title with the other groups and organizations. Hasan Taner Kerimoğlu, Osmanlı'da Devrim ve Fedakâran-ı Millet - Istibdat Dönemi Sürgün ve Firarilerinin Devr-i Hürriyet'te Mücadeleleri (İstanbul: Tarih Vakfı Yurt Yayınları, 2018), 121. In the coup d'état named the Bab-1 Ali Raid in 1913, the reasoning of the CUP's own action was the motivation provided by this title, which the Committee deemed itself worth of.

\section{History Studies \\ www.historystudies.net}


in 1918, however, the leaders of the Committee had to resign from the government and the Committee ended its existence with the decision of self-termination. Some eminent leaders of the Committee, such as Enver Pasha, Cemal Pasha, Talat Pasha, Dr. Bahaeddin Şakir Bey, and Dr. Nazım Bey immediately left the country. Nevertheless, the Unionists who stayed the country played an active role in the organization of the Turkish National Struggle by maintaining their political activities within the other political organizations.

\title{
1.2. From the "Heroes of the Freedom" to the "Traitors"
}

The first powerful opposition in the Early Republican period also came into existence within the circle of Unionists continuing their political concern, and the CUP maintained its direct existence on the political scene via these names until the assassination attempt on Mustafa Kemal Pasha in $1926 .{ }^{18}$ After the abolishment of the Unionists from the politics, the CUP has maintained its actual importance to date, due to both its distinctive role in Turkish parliamentary life and the history of the Turkish revolution, and the continued importance of the prominent political issues and actors in the recent history as one of the main elements in the political arguments in Turkey. Perceptions about Unionism, which developed in this period, and the political arguments based on these perceptions, have never ceased. However, in parallel to the changing political conjuncture in Turkey in time, the arguments of the perceptions were blended with the new concerns and concepts that emerged in relation with the new political paradigms in Turkish politics, and this has changed the meaning of the CUP over time.

The CUP's single-handed ownership in the ruling power during World War I burdened the responsibility of the destruction as a result of the defeat of the Ottoman Empire on it. The public's war-weariness turned into weariness about the CUP towards the end of the war. According to the public surveys conducted by Mark Sykes in Anatolia, in January 1918, the people primarily held Enver Pasha responsible for the deaths of soldiers in the fronts, the Sarıkamıs disaster, and the high cost of living. According to them, Enver Pasha and the CUP dethroned Abdülhamit II, lost the majority of the Empire's territories, sacrificed the survival of the state, and sold it to Germany and they condemned their own people to starvation by sending the Anatolian crops to Germany. Meanwhile, the Unionists had enjoyed with German gold in İstanbul. ${ }^{19}$

The opponents who remained on the sidelines until that time came forth after the closure of the CUP, and the biases emerging with the war-weariness of the people began to persevere. Thus, the first concrete ramification was the emergence of extremists anti-Unionism. Those who were obliged to maintain their opposition against the CUP from abroad after 1913 began to return to İstanbul after the defeat of the Ottoman Empire in the Great War, and wrote harsh political criticism against the CUP benefiting from the new atmosphere. ${ }^{20}$ The book published by Mehmed

${ }^{18}$ In addition, according to Erik Jan Zürcher, the governments in the early Republican era should also be seen as an extension of the CUP. Zürcher periodizes the time between 1908 and 1950 as the "Young Turk Age" with a general title. Although the assertion of Zürich is open to discussion, it is clear that the institutional existence of the CUP ended in 1918 but it has survived until today in terms of political intellectual and mental aspects. Erik Jan Zürcher, Modernleșen Türkiye'nin Tarihi, trans. Yasemin Saner Gönen, (İstanbul: İletișim Yayınları, 2000), 15-16.

${ }^{19}$ Türk Tarih Kurumu Mikro Film Arşivi, The Papers of Mark Sykes, DDSY2/4 Foreign Affairs and Travel (18881919), 4/172, January 1918 (est. date), Ms. And ts. Questions and Answers by Mark Sykes about anti-Turkish, German and Arab Propaganda.

${ }^{20}$ After the Bab-1 Ali Raid in 1913, the majority of the opponents of the CUP gradually went to Egypt and continued their opposition with media organs they published there. The executive board of the CUP decided to ban the press coming from Egypt in 1916 concerned that these articles would support the opposition to the CUP in the Ottoman public opinion. See BOA/HSDHADB/4/12/3; BOA/HSDHADB/4/7 /4. Thus, it seemed that all channels through which the opponents could call out the Ottoman public were blocked. After the defeat of the Ottoman Empire in the Great. War, in 1918, the CUP resigned from the cabinet and the opponents returned to Istanbul and got their political rematch. Anti-Unionism grew so much that the Party of Renewal (Tecedüt Frrkas1), founded by the Unionists who stayed in the country after the self-termination of the CUP, was closed down by a decree from the Cabinet (Meclis-i Vükela) on 5 May 1919 and all assets remaining from the Committee were confiscated. Many Unionists who stayed

\author{
History Studies \\ www.historystudies.net
}


Selahaddin Bey returning from exile in Egypt in 1918 was striking in terms of summarizing the political atmosphere of the era. In his book, Selahaddin Bey considered Unionism equal to servitude to Germans, and servitude to Germans equal to Anglophobia. He declared Anglophobia as treason and accused the Unionists of dethroning Sultan Abdülhamit and many more "sins". According to him, the Unionists were Zionists, Masons, German collaborates, and self-seeking persons..$^{21}$ In addition to Selahaddin Bey, Ali Nazif Süruri, who was among the statesmen of the Abdülhamit II era and exiled to the island of Lésbos after the declaration of constitutional monarchy, defined Unionists as a "cruel and tyrannical gang", in his book named Son Firsat (Last Chance), published between the Armistice of Mudros and the Treaty of Sèvres. He also accused them of heathenizing the state in favor of Turkism as well as "destroying and killing" millions of innocent citizens in the fronts and "maltreating" and "persecuting" Armenians, Greeks, and Arabs. ${ }^{22}$ Such examples increased so much that Asim Us summarized such an imaginary appearance of Unionism gained in the new era, starting with the Armistice of Mudros, as follows:

"The conflicts between Unionism and Ententism got so intense that concerns regarding the nation became forgotten in the disaster of defeat. Stigmatizing someone unagreeable as a Unionist was enough to discredit him."23

Being a Unionist in the period of Armistice was a flagrant offense. Fuat Bey, the Deputy of Divaniye, submitted his motion demanding the referral of the CUP governments to the Divan-1 Ali (Supreme Court) to the Chamber of Deputies on October 28th, 1918 due to the fact that the Unionists had gotten the Ottoman Empire involved in World War I, untimely and groundlessly, managed the war poorly, and were responsible for its defeat. Thereupon, the Chamber of Deputies started an investigation of the Unionists on November 6th, 1918. ${ }^{24}$ Britain's response to the event resulted in the judgment of the Unionists with the claim of "Armenian genocide". The Unionists began to be put on trial at the Martial Court House on April 27th, 1919. The proceeding started with the accusation of Armenian "relocation and massacre" against the Unionists but the scope was extended during the proceedings, and all kinds of liabilities within the duration of the time Unionists were in power were addressed by the court. ${ }^{25}$ The anti-Unionism reached the highest level in the March 1919 elections, and a merchant named İbrahim Hulusi demanded the annulment and repetition of the election in his petition to Mahmut Bey, the Governor of Karahisar-1 Sahib, since the candidate who won the municipal elections by the majority of votes in Sand1klı Kazas 1 of Karahisar-1 Sahib was a member of the CUP. ${ }^{26}$

The Turkish National Struggle movement and the political power struggles in the early Republican period strengthened the knot of Unionism, which evoked the economic destruction

in the country were put on trial and were sent to Malta. Tarık Zafer Tunaya, Türkiye'de Siyasal Partiler, vol.II (İstanbul: Hürriyet Vakfi Yurt Yayınları, 1986), 92-93, 101-102.

${ }^{21}$ Mehmed Selahaddin Bey made claims and accusations regarding the Unionists, praised the Sultan Vahdettin and Britain in his book. This attitude, which should be understood within the socio-political conditions of the period, was strikingly summarized in the long poem at the end of the book.: ““'Âferîn ey İttihâdın şanlı Enver'i / Arştan tâ ferşe indirdin livâ-yı ekberi / (...) / Ben de hayrânım yed i'câzına cem'iyetin / Sadmesiyle yıktı on yılda ser-â-pâ her yeri / Altıyüz yıllık muazzam devleti imhâ için / Milletin tâ can evinden saplamıştır hançeri / Yok mu şimdi ey Talât sana söyler isem / Kahrede Hakk sen gibi sun'î hamiyyet-perveri / (...) / İlm ü fenn ister, tükenmez servet ister şimdi harp / Cehl ile mağlûb olur mu Avrupa devletleri / (...). Mehmed Selahaddin Bey, İttihad ve Terakki'nin Kuruluşu ve Osmanlı Devleti'nin Yıkılışı Hakkında Bildiklerim, ed. Ahmed Varol (İstanbul: İnkılab Yayınları, 2017), 219-222.

${ }^{22}$ Ali Nazif Süruri, Son Firsat (İstanbul: Keteon Matbaas1, 1334 [1918]), 3-9.

${ }^{23}$ Asım Us, Gördüklerim, Duyduklarım, Duygularım - Meşrutiyet ve Cumhuriyet Devirlerine Ait Hatıralar ve Tetkikler (İstanbul: Vakit Matbaası, 1964), 20.

${ }^{24}$ Erol Şadi Erdinç, "Giriş", Osmanlı İttihad ve Terakki Cemiyeti Yargllamaları, vol.I, ed. Erol Şadi Erdinç (İstanbul: Türkiye İş Bankası Kültür Yayınları, 2018), XIII, XV.

${ }^{25}$ Erol Şadi Erdinç, "Giriş", Osmanlı İttihad ve Terakki Cemiyeti Yargılamaları, vol.II, ed. Erol Şadi Erdinç (İstanbul: Türkiye İş Bankası Kültür Yayınları, 2018), VII-IX.

${ }^{26}$ BOA, DH.İ.UM (Dahiliye İdare-yi Umumiyye), 12/3/1.

\author{
History Studies \\ www.historystudies.net
}


and the social and political crises that World War I left behind in the people's minds. The image of Unionism, which mingled with the war catastrophe, played an important role in the rise of antiUnionism as a dominant political discourse. The delegates at the Sivas Congress had to swear that they were not Unionists to avoid the possible identification of the Turkish National Struggle with Unionists in the public opinion, which had the risk of overshadowing the Turkish National Struggle movement. ${ }^{27}$ The requests of the CUP leaders, who fled abroad, to come to Anatolia were not accepted by the leaders of the National Struggle, and also certain precautions were enforced to prevent them from somehow coming back. The Cabinet Council banned the return of Enver Pasha and Halil (Kut) Pasha and other Unionists to the homeland with a decree on March 12th, 1921, and it was decided that they were to be deported if they entered the country. ${ }^{28}$ It was also decided with a new decree, dated May 24th, 1921, that Küçük Talat Bey (Muşkara), who was in Trabzon, and Mehmet Cemal Azmi Bey, who was in Sarıkamış, were to be deported. ${ }^{29}$ On the other hand, during the Armistice period, the CUP leaders abroad started to write their own memoirs in an attempt to overcome the accusations against themselves. ${ }^{30}$

In the early Republican period, a group of significant former Unionists like Kara Kemal, Cavit Bey, and Rauf Orbay took part in the opposition to Mustafa Kemal Pasha and his entourage, which was finally concluded in their elimination from the political scene, as their names were involved in the assassination attempt against Mustafa Kemal Pasha in 1926 in İzmir. Thus, the first factor behind the transformation of the CUP into an entrenched political argument in Turkey was the Unionists' political opposition against the founding ideology of the Republican Turkey as one of the anti-theses. ${ }^{31}$ However, this group was not compounded by all of the important Unionists under the opposition flag. Some of them, such as Hac1 Adil Arda, Mithat Şükre Bleda, Celal Bayar, and Şükrü Kaya, took on significant tasks by working in the Republican People's Party (RPP) in the new regime. In fact, considering the political sensitivity, they did not take a defending position in favor of the CUP and stayed away from the CUP until the current political

${ }^{27}$ Mustafa Kemal Atatürk, Nutuk, vol.1 (İstanbul: Milli Eğitim Basımevi, 1962), 88; Mahmut Goloğlu, Milli Mücadele Tarihi, vol.2, (Ankara: Nüve Matbaası, 1968), 13.

${ }^{28}$ BCA (Devlet Arşivleri Başkanlığı Cumhuriyet Arşivi), Başbakanlık, Kararlar Daire Başkanlığı (1920-1928), 2/38/18/1.

${ }^{29}$ BCA/ Başbakanlık, Kararlar Daire Başkanlığı (1920-1928), 3/22/15/1. However, Dr. Nazım Bey, Küçük Talat Bey and Halil Pasha were allowed to return in 1 August 1922. BCA/ Başbakanlık, Kararlar Daire Başkanlığı (1920-1928), 5/23/12/1.

${ }^{30}$ Talat Pasha wrote his memoirs in Germany to answer the accusations against him and Unionists. The memoirs were firstly published in the Yeni Şark newspaper in November and December 1912, yet, they were censored. Mehmed Talat Paşa, Hatıralarım ve Müdafaam, ed. Atatürk'ün Bütün Eserleri Çalışma Grubu (İstanbul: Kaynak Yayınları, 2006), 9. The texts were later serialized by Hüseyin Cahit Yalçın. Mehmed Talat Paşa, Talât Paşa'nın Anıları, ed. Alpay Kabacalı (İstanbul Türkiye İş Bankası Yayınları, 2000), 8-9. Cemal Pasha, on the other hand, wrote his memoirs in 1919, and the memoirs were translated to German and published in Munich for the first time. The publication of the memoirs in Turkey became possible in 1922. They were serialized in the Vakit newspaper in Latin letters in 1933. Cemal Paşa, Hatıralar, ed. Alpay Kabacalı (İstanbul: Türkiye İş Bankası Yayınları, 2001), 10.

31 The main criticism of the opposition, which consists mainly of former Unionists, was that the political authority was gradually gathering in the hands of a single authority. The increasing power granted to Mustafa Kemal Pasha and the decreasing influence of the former Unionist leaders on the political decision-making mechanism raised the tone of criticism and brought along the political power struggle. The principle of the decentralization and the order of national sovereignty emphasized in the program of the Progressive Republican People's Party can actually be considered as the opponents' request for functioning of a collective decision-making mechanism, with which the opponents were familiar in the Constitutional period. See: Rauf Orbay, Cehennem Değirmeni - Siyasi Hatıralarım, vol. 2 (İstanbul: Emre Yayınları, 1993), 139-140, 158-159, 165-168. Erik Jan Zürcher regarded these political movements in the early Republican period as a power struggle between the power groups within the CUP, and addressed the political competition between the former Unionist leaders and Mustafa Kemal Pasha and his entourage in line with this assertion. Erik Jan Zürcher, Millî Mücadelede İttihatçılık, trans. Nüzhet Salihoğlu (İstanbul: İletişim Yayınları, 2016), 179-212.

\author{
History Studies \\ www.historystudies.net
}


conjuncture changed. In his memoirs, Mithat Şükrü Bleda did not refrain from emphasizing his sincerity in his attitude:

"I was not contacting anyone politically or having political conversations. More precisely, I was refraining from this. I was avoiding persons engaged in such activities as possible and I was trying not to be seen even in the clubs or coffeehouses. I had worked to the best of my ability for the improvement of this nation for many years. Despite all our good intentions, we had not been able to reach our goal. However, the politics and the life of public service were over for me." 32

According to him, Mustafa Kemal Atatürk was the person to succeded in the things that the Unionists intended but failed to do for the country:

"[Mustafa Kemal's] unbreakable will, endless confidence in himself and his nation, and his awesome intelligence, foresight, brilliance was his secret to accomplish the things which seems impossible. It would be destined for Mustafa Kemal to save the beloved nation, which the CUP wanted to glorify but pushed to chaos, and to sustain it as an autonomous asset." 33

He mentioned that neither he nor the other Unionists had anything left to give to the nation in politics anymore. Therefore, he also stated that the opposition of the group that emerged in the National Assembly in 1920s, which mainly consisted of former Unionists against Mustafa Kemal Pasha, was meaningless. ${ }^{34}$

As the political sensitivities of the era began to change through the 1930s, however, the moderate writings of the former Unionists to restore the image attributed to the old spirit of the Committee as responses to the accusations faced over the years became more visible and increased in numbers. ${ }^{35}$ Thus, it was understood that there was still a group protecting the former spirit of the Committee, and a new way was opened to inquire about the nature of the CUP from a different perspective. Celal Bayar can be regarded as this sort at the outset with his comprehensive memoirs about the CUP, ${ }^{36}$ but there were also many others opposed to the accusations regarding the Unionists, or those like Muhittin Birgen and Hüseyin Cahit Yalçın accepting some of the criticisms towards the Committee, but intrepidly defending some of its aspects with a more moderate attitude. ${ }^{37}$ Kazım Nami Duru, who came forward with his works in the field of education in the Republican period and became deputy upon the request of Mustafa Kemal Atatürk in 1935 in two terms, added some advocating statements about the prominent leaders of the CUP such as Enver Pasha, Cemal Pasha, Talat Pasha and Sait Halim Pasha, Ziya Gökalp, Halil Menteşe and Dr. Nazım Bey in his memoirs he wrote in the second half of the

${ }^{32}$ Mithat Şükrü Bleda, Imparatorluk Çökerken, ed. Turgut Bleda (İstanbul: Destek Yayınevi, 2010), 148.

${ }^{33}$ Bleda, 145.

${ }^{34}$ Mithat Şükrü Bleda, who had remained as one the member of the executive cadre of the CUP as the Secretary General, was among the Unionists who deliberately preferred to completely stay away from the politics in the early years of the Republic. He frequently emphasized his gratitude and admiration for Mustafa Kemal Atatürk in his memoirs. He returned to the politics and became a member of the parliament by the request and order of Mustafa Kemal Atatürk in 1935. His memoirs were published by being simplified by his son, Turgut Bleda after his death. Bleda, 143, 146, 147, 149-156, 164-165, 175-179.

35 Although the memoirs written by Ziya Şakir (Soku) Bey between 1932 and 1935 brought some criticisms about Unionism, it was the product of an effort to turn the public's perception on Unionism, especially on Talat Pasha and his circle, which he had been also a part of, in a positive way. Ziya Şakir Soku, Ittihat ve Terakki Nasıl Doğdu? (İstanbul: Akıl Fikir Yayınları, 2018); Soku, İttihat ve Terakki Nasıl Yaşadı? (İstanbul: Akıl Fikir Yayınları, 2018); Soku, Ittihat ve Terakki Nasıl Öldü? (İstanbul: Akıl Fikir Yayınları, 2018). The circles Ziya Şakir symphatized in the CUP are clearer in his writings serialized in 1943 first time: Soku, Paşalar - Talat-Enver-Cemal (İstanbul Kaknüs Yayınlar1, 2010).

${ }^{36}$ Celal Bayar, Ben de Yazım, vol.I (İstanbul: Türkiye İş Bankası Kültür Yayınları, 2018); Bayar, Ben de Yazdım, vol.II (İstanbul: Türkiye İş Bankası Kültür Yayınları, 2018); Bayar., Ben de Yazım, vol.III (İstanbul: Türkiye İş Bankası Kültür Yayınları, 2018).

${ }^{37}$ See: Birgen, Ittihat ve Terakki'de On Sene; Hüseyin Cahit Yalçın, Siyasal Anılar, (İstanbul: Türkiye İş Bankası Kültür Yayınları, 2000).

\author{
History Studies \\ www.historystudies.net
}


1950s. His following reproachful words are convenient to reveal the nature of the writings of the era:

"I would not want to talk about these names in such way in my memoirs. However, they are still mentioned in a humiliating way. I mentioned these men of the CUP as I have an intrinsic rebellion against this dishonor." 38

Thus, the developing perceptions related to Unionism, first, shaped the language of the historical primary sources from the era. This language obtaining its structural characteristics from extremist alternative political arguments oscillating between the actions and reactions had the function to directly convey the irrationalized discourses of the era. Second, the debates on the axis of the political arguments shaped in relevance to perceptions about Unionism maintained its presence and power, and were moved to the Republican politics. This caused the supporters of each political ideology that emerged in the Republican period to identify a political attitude regarding the CUP. Thus, the political language of the time gained a political continuity.

\title{
2. Preconceptions on Unionism and Historiography of the CUP
}

\subsection{Unionists as "the Zionist Lackeys"}

Another factor in the continuity of the existence of the CUP as a political argument in Turkey derived from the right conservative community's pursuit for historical legitimacy sources. This time, the Unionists were accused of destroying the Empire with their arbitrary treatments by dethroning the Sultan Abdülhamit II. According to this argument, Abdülhamit II, in fact, ruled the Empire without losing single land with a perfect strategy and carried the flag of the caliphate to the highest level. Unionists, on the other hand, gave in to their personal ambitions, dethroned the Great Emperor Abdulhamit Han, and destroyed the Empire whether intentionally or in ignorance with their unreasonable policies. ${ }^{39}$ The work by Necip Fazıl Kısakürek, written to defend Abdülhamit II, was mainly effective in the re-emergence of this approach in the Republican period. However, this approach did not end with him. ${ }^{40}$

The feeling of aggrievement based on Abdülhamit II was carried so far that Unionists were virtually demonized against Abdülhamit II. Even conspiracy allegations that were made, such as "Zionist lackeys", "enemies of the religion" and "the collaborators of foreign states having designs on the territorial integrity of the Ottoman Empire" by alleging some of the Unionists" Masonic connections, were brought to the agenda again. ${ }^{41}$ Even a fictional memory book attributed to Abdülhamit II was published to reinforce such allegations. ${ }^{42}$ Although it was revealed that the statements in this book had nothing to do with Abdülhamit II, and this was a fictional text

${ }^{38}$ Kazım Nami Duru published his memoirs between 1957 and 1959 for the first time. Kazım Nami Duru, Hatıralar: Ittihat ve Terakki/Cumhuriyet Devri/Makedonya Hatıraları, ed. Mustafa Bekmezci (Ankara: Altınordu Yayınları, 2017), 67.

${ }^{39}$ For a detailed analysis of the perceptions of Abdülhamid II, see, Serkan Yazici, "Sultan II. Abdülhamid Örneğinde Tarihsel Algılamanın Değişimi”, History Studies International Journal of History, vol. 6, no. 5 (September 2014): $242-244$.

40 İbrahim Şirin, "Türkiye'de İttihatçıllk Algısı ve İttihat ve Terakki Çalışmaları", Türkiye'den Aydın Portreleri: Kurtuluş Kayalı, ed. Aytaç Yıldız (İstanbul: Doğu Batı Yayınları, 2018), 264-265.

${ }^{41}$ In his book, Ahmet Şimşirgil persisted in using the similar accusing expressions for the Unionists like the ones who "led the Empire to destruction", "served to the interests of the foreign states", "were dictators", "Jewish" or "Jewish converts", "Zionists", "co-conspirators of the Westerners," and "Masons". Ahmet Şimşirgil, Kayl - Osmanlı Tarihi X, II. Abdülhamid Han (İstanbul: Timaş Yayınları, 2018), especially 208, 215, 217, 218, 219, 221, 222, 251. For similar claims, see: İhsan Süreyya Sırma, II. Abdülhamid'in İslam Birliği Siyaseti (İstanbul Beyan Yayınları, 1989), 20, 114, 115, 124, 125, 129, 132.

${ }^{42}$ See: Ali Birinci, "Sultan Abdülhamid'in Hâtıra Defteri Meselesi”, Dîvân İlmi Araştırmalar, vol.19 (2005): 177-194; Y. Hakan Erdem, Tarih-Lenk (İstanbul: Doğan Kitap, 2017), 320-339.

\author{
History Studies \\ www.historystudies.net
}


written afterward, the researchers continued to use the fictional memory book as a primary source in their academic studies. ${ }^{43}$

\title{
2.2. Unionists as "the Heroes of the Freedom"
}

A new political discourse highlighting and praising important Unionist figures like Enver Pasha, in particular, and other Unionists like Talat Pasha, Cemal Pasha and Kara Kemal was built with the independent presence of the right-nationalist view in the political scene. This view focusing on the patriotism of the Unionists adopted the idea that Unionists were heroic citizens with great morality who internalized the glorious spirit of the "Sacred Committee" excluded from the feeling of personal benefit by emphasizing the personal sacrifices of the Unionists during events like the World War I, and even creating new and exaggerated sacrifice narratives based on victimhood about them. The new political discourse caused the notables of the CUP to be presented in political arguments again by flagging them. In fact, although the Committee had withdrawn from the historical scene, it gained new spiritually devoted followers. ${ }^{44}$

This discourse soon was reflected in the academic field as well, and continued to this day. As the counterargument of the ascription of "treason", the title of "hero of the freedom" from 1908 was brought up again. The praising of some notable members of the CUP, in particular, of Enver Pasha, enabled the historiography based on the narration of the great man to be maintained in academic studies in this field. Raşit Yılmaz's following statements in the conclusion chapter of one of his studies after he emphasized the necessity of being based on the historical documents to develop an opinion about the CUP can be a good example: "In my opinion, the most important aspect of the Committee is that most of its members were the most virtuous people of their time. (...) I am talking about a complete and perfect "virtue" including the heart, mind, and action. ${ }^{45}$

\subsection{Unionists as "the Dictators"}

The CUP was re-addressed as the symbolic expression of anti-democratic values with socialist and left-liberal views. The underlined narrative on Enver Pasha, Talat Pasha, and Cemal Pasha became integrated with the definition of a de facto triumvira and the former anti-Unionist allegations began to be expressed with clearer language, including phrases describing the dictatorship or despotism attributed to the era. According to Murat Belge, the 1908 movement was not a revolution, but a bureaucratic coup d'état formed with the involvement of a group of military officers and civil servants. The CUP was "more of a gang than a revolutionist organization". According to Belge, the objective of the CUP was not to make radical changes but to rescue the Empire from collapse; thus, it could only be a conservative militarist organization

\footnotetext{
${ }^{43}$ Since there are so many examples, it was not possible to present them all here. For some of them, see: Arzu Çiftsüren, "Şibli Numani'nin Seyahatnamesinde II. Abdülhamid ve Gazi Osman Paşa", Doğu Araștırmaları, vol.18 (2018): 89; Fatma Müge Göçek \& Murat Özyüksel, "The Ottoman Empire's Negotiation of Western Liberal Imperialism”, Liberal Imperializm in Europe, ed. Matthew P. Fitzpatrick (New York: Palgrave Macmillan, 2012), 204-205,216; İsa Sergin, Cumhuriyet ve Cumhuriyet Öncesi Türk Aydınlarının Hatıratlarında Sultan II. Abdülhamit Imgesi, (Master's Thesis, İstanbul Sabahattin Zaim University, 2020), İstanbul, 100; Onur Kazanc1, Bir Yıkıcı Liderlik Örneği: Sultan II. Abdülhamid, (PhD diss., Ege University, 2019), İzmir, 72, 77, 90, 91, 98, 101, 105, 110, 150; Nesli Tuğban Yaban, Italya Basınında Sultan II. Abdülhamid Dönemi Osmanlı Imgesi, (PhD diss., Hacettepe University, 2018), Ankara, 75,78 .

${ }^{44}$ See; İlyas Kara, İttihatçılar Ölür, İttihatçılık Ölmez (İstanbul: Kamer Yayınları, 2020).

45 H. Raşit Yılmaz, "İmparatorluğa Veda Arifesinde Bir Nesil: İttihatçılar - 1908-1913 Cemiyetin Varoluş Mücadelesi”, Bayrak Kalpak Revolver - Ittihat ve Terakki Cemiyeti, ed. Hakan Boz (Ankara: İhtimal Dergisi Yayınevi, 2016), 33-34. To the importance of the emphasis on Enver Pasha in the right-nationalist view, also see: Oğuzhan Murat Öztürk, "Dönem Hatıratları Işığında İttihat ve Terakki ve İttihatçılar”, İttihat ve Terakki Cemiyeti Vatan Namus Ittihad, ed. Hakan Boz (İstanbul: Historia Yayınları, 2018), 231-254. For a criticism from the nationalist perspective of İkbal Vurucu on the conservatives' discourse of Unionism, see: İkbal Vurucu, "Yeni Türkiye'de Tarih Savaşları”, Bayrak Kalpak Revolver - Itttihat ve Terakki Cemiyeti, ed. Hakan Boz (Ankara: İhtimal Dergisi Yayınevi, 2016), 332-349.
}

\author{
History Studies \\ www.historystudies.net
}


but not a revolutionist. The militarist authority, which began to increase its power in politics with this coup, maintained its influence until the Democrat Party became the party in power with elections in 1950 in Turkey, and formed the backbone of the power structure in Turkey. ${ }^{46}$

As a result of the changing political atmosphere in Turkey, the language of left suggestions about Unionism has become closer to the right conservative Unionism arguments. İdris Küçükömer, for instance, mentioned that in Turkish political history, the left became the right, and right became the left. According to Küçükömer, the reactionists of Turkey were the members of the CUP, which was getting its power from the government bodies, and the RPP was the successor of the CUP while the progressivists were "Islamist masses in the right-wing" and political organizations based on these masses such as the Freedom and Entente and the Democrat Parties. ${ }^{47}$ Thus, he searched for his historical resources of his view tending to the left-wing perspective mostly within the Islamist arguments. This caused the arguments of the Islamist perception had an important role in his way to describe the CUP in his study in which he suggested a continuity between the CUP and the RPP in the context of class formation. In fact, Küçükömer started his study with the following citation from Said Halim Pasha; "Had Sultan Hamid not been born, his contemporaries would have given rise to a Sultan Hamid" but added a footnote to state that "However, Said Halim Pasha got involved with the Unionists then and was corrupted." 48 While Abdülhamit II maintained a balanced policy that he "mastered" in foreign policy against the difficulties encountered by the Ottoman Empire and prevented the Zionists from achieving their goals, the CUP adopted the despotic government style, which it had opposed to at the beginning, and accelerated the downfall of the Empire with its status quo policies. According to Küçükömer, the etatism practices of the CUP interrupted the improvement of the production by impairing the domestic producers; thus, imported Western goods became widespread in the market instead of domestic products. On one hand, this situation benefited Imperialist states and on the other hand, it enabled the Unionist military officers and civil servants to mediate the access of imported products to the public to acquire wealth. The Freedom and Entente Party, expressing the class interests of the public, was suppressed, and taken down by the Unionists. Moreover, the reason why the Unionists put the Ottoman Empire into World War I was to ensure the continuity of their governmental privileges in the power. ${ }^{49}$

With the inclusion of historical dilemmas, such as nation building policies and the Armenian Question, into the argument of the continuity, the matter became more complex. It became more widespread that facing "the Armenian genocide" is a critical step in terms of political progress in Turkey. ${ }^{50}$ This attitude, on the other hand, encouraged Turkish nationalist segments to provide more powerful responses. Such an extent that the conference of "Ottoman Armenians" planned to be held in Boğaziçi University in 2005, faced harsh criticisms even before it was held, and it was eventually annulled by a court's decision of stay execution. ${ }^{51}$

\footnotetext{
${ }^{46}$ Murat Belge, Militarist Modernleşme - Almanya, Japonya ve Türkiye (İstanbul: İletişim Yayınları, 2012), 14, 171172, 576-578, 587-588, 594-597.

47 İdris Küçükömer, “Batılaşma” Düzenin Yabancılaşması, (İstanbul: Bağlam Yayınları, 1994), 72, 87-93.

${ }^{48}$ Küçükömer, 13.

${ }^{49}$ Küçükömer, 70, 74-78, 80-81, 86.

50 İbrahim Şirin criticized this claim asserted by Erik Jan Zürcher and Taner Akçam as follows: "[With this approach] Can truth be sacrificed to the ideal for a more humanist society? Or the question is for this ideal whether the history can be exploited, and even can documents and memories be produced? Stuck between social engineering and the profession of historiography, the historian must first remain faithful to the truth." Şirin, "Türkiye'de İttihatçılık Algısı ve İttihat ve Terakki Çalıșmaları”, 275.

${ }^{51}$ Although the conference was annulled by the court's decision to stay execution, it was reorganized at Bilgi University a few months later. Oktay Özel wrote two articles, one after the cancelation of the conference and one after the conference was held. In his first article, Özel stated that it is a problem that historiography is influenced by the extremely politicized environment in Turkey, and in order to solve a sensitive issue such as the Armenian Question, it should be allowed to the historian to focus on his work in peace and silence, and in every aspect, to discuss with
}

\author{
History Studies \\ www.historystudies.net
}




\title{
2.4. Reconsidering Unionism in Kemalism and Islamism
}

The approach alienating the history of the CUP and perceiving it as the antithesis of the founding national ideology progressively ended in the Kemalist sphere. Heroizing Abdülhamit II had developed as a way of criticism not only against Unionism but also against Kemalism over Unionism. Therefore, a new approach emerged, which did not embrace the Unionist legacy but accorded with Unionists in the criticism of the Hamidian regime. In the new edition of his work named the Turkish Revolution History in 1962, Yusuf Hikmet Bayur mentioned about the partisanship of Abdülhamit II becoming more visible within 22 years: "Those who cannot accept secularism and even slightly the Republic whether due to their beliefs or because it does not serve their purpose began to praise the past periods and even advocate them." Before listing the responses to this approach, he clearly explained that he has no intention of taking in the Unionists:

"Those advocating for Abdülhamit can dwell upon a single point if they have their heart in it, and this point is that those dethroning the sovereign did greater harm to the state; thus, this change was not good for the Ottomanism. This is partially correct but it is a fact that it was not possible for Abdülhamit to be able to continue his rule anymore neither morally nor financially in 1908." 52

In the approach of the left-nationalist Kemalist circles, the CUP, a rupture occurred, especially with the influence of Sina Akşin. Akşin considered the CUP as the main milestone paving the way for political, intellectual, social, cultural, and economic developments of the early Republican period and preparing for the Republican regime during his search for the roots of the Republican revolutions. ${ }^{53} \mathrm{He}$ named the 1908 Movement as a bourgeois revolution: "Bourgeois revolutions are named as the bourgeois democratic revolution as they aim to end the restricting and unequal environment of the feudal order and bring freedom and equality, in other words, democracy." Akşin named the Ottoman society before 1908 as a feudal society and stated that the CUP came forward "to create a modern society to end this order". Thus, the first social break before the Republic occurred in 1908, but the goals of the era could not be achieved completely. The democratic nationalist movement, on the other hand, appeared as the continuity of the Constitutional Revolution, but a radical separation occurred with the abolition of the sultanate and the proclamation of the republic.

Finally, it must be stated that an opinion reconciling the Islamism with the Unionists emerged in the literature. Unlike the left-nationalist approach, this approach dominant in İsmail Küçükkılınç's remarks proposed that the CUP did not break its connections with the Islamism even when it applied the Turkism policies. On the contrary, the notable members of the CUP made intentional efforts to reinforce the emphasis of Islam in Turkish identity intentionally and faithfully while building the Turkish identity and their policy of Turkism never excluded other

his colleagues without being part of any political agenda. He also emphasized that bringing up the relevant studies to the agenda before the public while historians are continuing their studies on such matter would prevent the historians from investigating the matter objectively, and lead historians to move them away from the scientific dimension. Thus, at the time it was organized, the content of the emphasis in the conference were influenced to a degree by the previous court decision of stay execution and the political pressure encountered. As stated by Oktay Özel in his second article, "While it should have been only a scientific meeting, the conference had become prominent as a struggle for democracy, science and freedom of thought since its process of planning vis-à-vis sensitivity of the subject and the environment." Oktay Özel, Dün Sancısı - Türkiye'de Geçmiş Algısı ve Akademik Tarihçilik (İstanbul Tarih Vakfı Yurt Yayınları, 2012), 129-134;135-139.

52 Yusuf Hikmet Bayur, Türk Inkılap Tarihi, vol. I, no. II (Ankara: Türk Tarih Kurumu Basımevi, 1991), 217-218.

${ }^{53}$ Akşin answered the claims of the supporters of Abdülhamit II and Vahdettin in the preface of his book dated 2008. See Akşin, Jön Türkler ve İttihat ve Terakki, 11-23.

\author{
History Studies \\ www.historystudies.net
}


Muslim entities. ${ }^{54}$ Moreover, Küçükkılınç addressed the assassinations organized by the Unionists, which were among the main points of criticism for the Islamist circles, as follows:

"It is a fact that the Unionists sometimes appealed to guerilla methods as a means of political suppression and this can never be legitimate, justifiable, and interpretable; however, the determinant reason behind their decisions to murder or assassinate someone did not depend on the opposition of the victims to the CUP but depended on their "treason". On the other hand, those hanging the Unionists and murdered Kara Kemal with a gun were sure about their patriotism and dignity to the nation". ${ }^{55}$

As it can be understood, the rapidly changing political agenda and relations in Turkey can be directly reflected in the studies on the CUP and create polygamies. This led the literature to become more prosperous but complex at the same time. There might be an understanding of "survival" in the origin of these types of polygamies. As the Armenian Question became a current issue in the world again with the demands to recognize the genocide after the 1980s, the CUP, which was held responsible for the massacre, turned into a matter of principle focusing on the understanding of the survival of the state. In this view, the relocation policies of the Unionists are among the main factors to enable the formation a national Turkish state. ${ }^{56}$ One of the initial resources reflecting this understanding of survival can be found in the memoirs of Hüseyin Cahit Yalçın. Strongly opposing the relocation of the Ottoman Armenians in 1915, Yalçın later mentioned his regret about his first reaction and his belatedness to recognize the necessity of the Armenian relocation act because of its mighty share in enabling the Turkish National Struggle to succeed in the independence of the Turkish state. ${ }^{57}$

\section{Perceptions about Unionism and Methodological Problems}

\subsection{From "Metaphor" to "Homology"}

The historical continuity formed with alternative perceptions about Unionism, which had been shaped since the establishment of the CUP until the end of its active political existence with the İzmir assassination attempt, which were conveyed to this day, brought along two methodological problems in the CUP studies. The first one is based on the gradual integration of the perceptions with the concerns, priorities, and concepts of the ongoing period, in short, their adaption to time. In other words, the main political arguments regarding Unionism maintained their existence with a similar appearance, but the focal points of the existing arguments on Unionism were able to alter in line with new debates based on the changing agenda in Turkey and new concepts featured by these debates. This situation imported the concerns, priorities, and concepts of the Republican period to the history of the CUP; thus, it became a habit to retrospectively investigate the history of the CUP.

The habit of addressing the history of the CUP as a particle of the retrospectively reading Republican Turkey, which pose a sort of anachronistic danger regarding the studies on the CUP, mostly based on the fact that following researchers perceived the assessment of Tarkk Zafer Tunaya that the Second Constitutional period was the "laboratory" of the Republican period as a homology. Tunaya's assessment was not a homology, but a metaphor if it was based on the date when he wrote his work. Tunaya was born in 1916, he completed his education in the 1930s and started working in the 1940s. He published his famous work, named the Political Parties in

\footnotetext{
54 İsmail Küçükkılınç, Jön Türklük ve Kemalizm Kıskacında İttihadçılık, (İstanbul: Historia Kitap 2018), 80-90, 374376, 391. It should also be noted that Küçükkılınç completely rejects the emphasized connection between Kemalism and Unionism. According to Küçükkılınç, the Turkish National Struggle is the product of the Unionists' achievement. Küçükk1lınç, 373-380, 396.

55 Küçükk1lınç, 234, also see 394-395.

${ }^{56}$ Küçükkılınç, 386-390.

${ }^{57}$ Yalçın, Siyasal Anılar, 324.
} 
Turkey, in 1952. During that time, the arguments regarding perceptions about Unionism had continued to vary day-by-day and the CUP studies were so far from being an area of academic interest. The study by Tunaya was the first extensive historical text drawing attention to academic sensitivities about the CUP. Thus, it can be understood that Tunaya's metaphor of "laboratory" was to draw attention to the scientific-historical sensitivities of the studies on the CUP and to emphasize the importance of the serious academic researche about the CUP in a historiographical context. On the other hand, this metaphor was perceived and adopted as homology in the later studies, and the origins of the early Republican policies began to be searched in the Second Constitutional period and more specifically in the history of the CUP, and the concepts of the early Republican political agenda were imputed to the political manners of the Constitutional regime. ${ }^{58}$

\title{
3.2. From "Rhetoric" to "Canon"
}

The second methodological problem in the studies on the CUP, due to the continuity between the perceptions about Unionism, is related to its impact on the use of primary sources. This situation allowed a direct relationship between the researcher and the sources. It could conclude in a path dependency for the researcher between the perception on Unionism he/she was affected by, and his/her selection of the primary sources for his/her study. In other words, each researcher could continue to follow the language of the primary source in compliance with their bias. Thus, researchers did not experience any difficulty in finding a source that ratified and fortified their opinion due to the continuity between the perceptions. In fact, researchers with different preconceptions and perceptions could also obtain different conclusions from a same source due to their own biases.

In the studies on the Armenian Question, it is possible to find examples for these types of relationships between the researcher and sources shaped by the apparent perceptions. Indeed, Selim Deringil likened studying the Armenian Question to entering a minefield. The connection between the researchers studying the Armenian Question and ideological perceptions identified the relation between the parties and documented in the grip of "denialism" or "treason" as well..$^{59}$ Furthermore, Deringil turned 14 archive documents about the Armenian Question into separate cases and pointed out how opposing deductions could be made from the same document with different approaches and questions to the document, and how both relocation and genocide claims could be obtained from the same documents. Accordingly, as Deringil stated, "It is also incorrect that the Ottoman Archives always reflect the objective truths. (...) materials that can support a biased, partisan positioning can always be found." 60

Since the primary sources about the CUP are limited or difficult to be accessed by researchers, intertextuality it is inevitable in the use and transfer of primary sources. It is remarkable that the majority of the citations made by researchers with similar or alternative opinions from each other, if their objectives were not directly opposed to a suggested assertion, though obvious criticism is rather rare considering the literature, are the citations from the primary sources of other researchers' works. Furthermore, only a few researchers using the information that another

\footnotetext{
${ }^{58}$ For the conceptual analysis, see: I. Bernard Cohen, "Analogy, Homology, and Metaphor in the Interactions between the Natural Sciences and the Social Sciences, Especially Economics”, History of Political Economy, vol. 25, no.1 (1993): 5-44.

59 Selim Deringil, Simgeden Millete - II. Abdülhamid'den Mustafa Kemal'e Devlet ve Millet (İstanbul: İletişim Yayınlar1, 2009), 219-221.

${ }^{60}$ Deringil, 247. Considering that Deringil's views on the Armenian issue are close to a certain side, the article by Şenol Kantarc1 written as a response to Deringil's article by expanding the cases presented by Deringil should be looked through: Şenol Kantarcı, "Ermeni Sorununa Pencereden Bakmak ya da Manzaranın Bütününü Görmek: Taraflar, Tarafsızlar ve Tarafsız Olduklarını Beyan Etme Zorunluluğu Hissederek Taraf Tutanlar mı Var?", OTAM Ankara Üniversitesi Osmanlı Tarihi Araştırma ve Uygulama Merkezi Dergisi, vol. 19, no. 19 (2006): 199-217.
}

\author{
History Studies \\ www.historystudies.net
}


researcher conveyed from a resource questioned the contextualization or possible intervention on the citation of the researcher who had first cited it. When a researcher uses the primary source containing the original citation from another secondary source without checking and questioning it due to various reasons, it becomes inevitable for an incorrect information or an extremist interpretation to be inured and to evolve into one of the general acceptances and to turn into a canon in the literature on the CUP, regardless of the opinion. The best example of these arguments, which transmitted between the texts containing completely alternative opinions to each other in terms of the conclusions, is the assertion of Turkism and Turkification policies associated with the Unionists.

Zafer Toprak objected to the claim that the goal of the Unionists to "turn the Ottoman Empire into a nation-state which a single entity, the Turkish entity would be dominant in", and examined how this retrospective opinion turned into a general acceptance in the literature in one of his articles. Toprak criticizes the claims that the Unionists had an "ethno-nationalist" understanding and conducted a type of "homogenization" policy, which gained a "pathological" character during World War I, across the Empire. ${ }^{61}$ Indeed, "Turkish nationalism" and "Turkification" policies associated with the CUP are not only the core arguments asserted by diaspora historians, but also common ones accepted by all other social scientists and historians. As stated by Toprak, "while historians in Turkey 'Turkify' the history on behalf of the 'nationalism', they unconsciously contribute to the 'genocide' allegations" as a result of "carelessness" and "indolence" displayed especially by historians studying in the field of the history of education in a nationalist perception. ${ }^{62}$ When Toprak investigated this imperfect argument, he especially paid attention to the citation that Osman Nuri Ergin made with deductions and additions from Article 6 of the Mekâtib-i Hususiyye Talimatnamesi (The Regulation on Private Schools), dated 1915, in the 4th edition of his book named Türkiye Maarif Tarihi (Educational History of Turkey):

"It is mandatory for Turkish Language and the Turkish History and Geography to be taught by Turkish teachers in Turkish in private schools where the language of the education is different from the official language." 63

When it comes to the original version of the statement in the regulation, it was as follows, as emphasized by Toprak:

"It is mandatory for Turkish language and the Ottoman history and geography to be taught in private schools where the language of the education is different from the official language. (...) The Ottoman history and geography could be taught in the language of the education of the school." $" 64$

The only correct phrase in the first citation, the "teaching of Turkish [to be taught]", was not a reform made by the Unionists the first time. ${ }^{65}$ Toprak also identified that Hasan Ali Koçer and Yahya Akyüz used the citation by Ergin in their studies, and argued that the Unionists pursued a "Turkism" and/or "Turkification" policy in education based on this citation. Mustafa Gencer and Mehmet Emin Elmacı also cited Article 6 directly from Koçer in their studies; and thus maintained the false citation. ${ }^{66}$ Halit Aytekin, on the other hand, checked the regulation and used the correct citation in his study; however, he included the interpretation that "These institutions were

\footnotetext{
${ }^{61}$ Zafer Toprak, “Bir Hayal Ürünü: İttihatçıların ‘Türkleştirme Politikası””, Toplumsal Tarih, vol.146 (2006): 14-15.

62 Toprak, 17.

${ }^{63}$ Toprak, 17.

${ }^{64}$ Toprak, 19.

${ }^{65}$ For detailed information, see: Muttalip Şimşek, “Osmanlı Devleti'nde Türkçe'nin Gayrimüslim Okullarında Mecburi Hale Getirilmesi ve Uygulanması”, OTAM Ankara Üniversitesi Osmanlı Tarihi Araştırma ve Uygulama Merkezi Dergisi, vol.43 (2018): 203-205.

${ }^{66}$ Toprak, "Bir Hayal Ürünü: İttihatçıların ‘Türkleştirme Politikası”’, 17-19.
}

\author{
History Studies \\ www.historystudies.net
}


excluded from being slot of corruption and were prohibited from providing education contrary to Turkish culture, religion and morality [with this regulation]", and asserted a meaning that cannot be understood from the original text of the regulation like the others did. ${ }^{67}$ Toprak's study is important in terms of revealing the neglect of researchers towards primary sources and how citations and opinions obtained from primary sources can reflect into future studies. ${ }^{68}$

It is clear that the suggestions of researchers avoiding certain political perceptions and overinterpreting regarding the CUP did not arouse as much interest as the normative suggestions of the abovementioned studies in the literature. Bernard Lewis's judgments that a military dictatorship formed in Turkey between 1913 and 1918, and the complete power and control were in the hands of a triumvirate consisting of Enver Pasha, Cemal Pasha, and Talat Pasha, became two typical canons in CUP studies. ${ }^{69}$ In fact, the suggestions of Erik Jan Zürcher that the habit of reading of the history of the CUP as a militarist power, including the years of World War I, is a defective approach ${ }^{70}$ or the suggestions of Feroz Ahmad, that interpreting the management and decision-making mechanisms of the CUP as a triumvirate consisted by Enver Pasha, Cemal Pasha and Talat Pasha is a superficial perspective, and that the CUP should first be understood through the actions of the Head Office (and its entourage), ${ }^{71}$ has not aroused the necessary interest and had not ha a solid correspondence in other studies as of yet.

\title{
Conclusion
}

The perceptions about Unionism continuing between the primary sources and the CUP studies are not obstacles to writing and understanding the history of the CUP, but neglecting the perceptional interaction is a problem for the future progress of the literature. Judgments emerging around the perceptions about Unionism have been reiterated and reached general acceptance in time through the transfer of the language in the sources to the academic studies as in the example of Lewis. Remarkably, critical texts are limited compared to the literature expanding day-by-day, as the unknowns about the history of the CUP are studied more (if the accusations and the answers of the text shaped around the certain perceptions about Unionism are disregarded). It is worrisome that the published historiographical critics are gradually being replaced by a format similar to book reviews. In addition, the responses to the merely written criticisms reveal that the

\footnotetext{
67 Toprak, 19-20.

${ }^{68}$ It should be emphasized to prevent any misunderstanding that Zafer Toprak does not object to the idea that the Unionists were Turkish nationalists in this article. He objects to the ambiguity in the attributed meaning of the term of Turkish nationalism used in the literature and the dedication of an "ethno-nationalist" notion, which gained prominence only in the early Republican period, into the Unionist's idea of Turkish nationalism, which was originally combined with an Ottomanist notion as he claimed. On the other hand, it should be noted that some new resources from the CUP have emerged since 2006, when Zafer Toprak wrote this article. It can be understood from the minutes of the meetings, continuing from October 1916 to the spring of 1917, and consisting of the ones from the core executive cadre of the CUP like Hacı Adil (Arda), Kara Kemal, Ziya (Gökalp), Halil (Menteşe), Hüseyin Cahit (Yalçın), Dr. Nazım and Talat Pasha, that important discussions took place in the context of Turkification to assimilate and integrate both non-Muslim and non-Turkish Muslim communities living within the borders of the Empire. Those documents indicated that the ethno-nationalism relation of the Unionist should be re-considered at least from 1916. See: BOA, HSDHADB, 4/1; BOA, HSDHADB, 4/4/1/7-14.

${ }^{69}$ Bernard Lewis, The Emergence of Modern Turkey (Oxford: Oxford University Press, 1961), 221.

${ }^{70}$ In his related article, Zürcher evaluates the civil and military roles and identities of the names in the Ottoman cabinet between 1914-1918, and compares the distribution of seats between soldiers and civilians in the cabinet with those of other countries waging in the Great War. Additionally, he tries to understand the extent of interventions of military and civilian persons within the decision-making mechanisms in each other's field. In this study, Zürcher suggests that the Ottoman Empire cannot be evaluated with a militarized administration during the Great War. Erik Jan Zürcher, "Young Turk Governance in the Ottoman Empire during the First World War", Middle Eastern Studies, vol. 56, no. 6 (2019): 897-913.

${ }^{71}$ Ahmad, Ittihat ve Terakki 1908-1914, 219-222.
}

\author{
History Studies \\ www.historystudies.net
}


researchers' tolerance to criticism gradually dissolves. ${ }^{72}$ On the other hand, more criticisms are needed to analyze the relationship between the primary sources and the contextualization of the CUP researchers in order to profoundly understand the history of the CUP in in the future progress of the area studies.

The CUP, which provided the most important impulse in the re-proclamation of the Constitution, created a privileged position for itself in the Ottoman political life after 1908, by using extremist political discourses and aggressive political policies. The "sacredness" attributed to the CUP by itself after 1908 was not limited to be a rhetoric phrase. The self-attributed "sacredness" became one of the main motivation sources determining the Unionist dynamic and the political character of the era. The Committee identified its power with the survivance of the state and intertwined with governmental mechanisms by developing many methods and tools that would increase its political influence with its subsidiary institutions and organizations during the time until 1918. The Committee also nullified opposing movements using this position. On the other hand, the Unionist discourse radicalizing the political rationality was quick to create its own opposite at the same level of defamation and severity like a pendulum.

The new political ideologies that developed throughout the Republican history adopted a particular attitude toward the CUP and brought the continuation of the former political perceptions about Unionism, which had been shaped from the establishment of the CUP until the abolition of itself. Political arguments developed in the first quarter of the 20th century, which were far from reflecting the rationality of the era were transferred to the Republican period. This is also reflected in the studies on the CUP by combining them with the new concepts and meanings emerging with new political developments in the Republican. In this regard, normative determinations, and conceptualizations, which were agitatedly or apologetically deduced by CUP researchers with different opinions, are the continuity of the political arguments of the CUP decade. Therefore, texts formed around alternative perceptions can be regarded as a part of direct extension of the history of the CUP. In other words, it can be considered that the history of the CUP did not conclude regarding the continuation of the political context. Not the physical appearance of the CUP, but its imaginary existence, continues as a part of new political structure in Turkey and indeed, as one of the key factors defining their holistic characteristics, and complicates understanding the CUP at a rational level.

\footnotetext{
${ }^{72}$ In a recent discussion between İbrahim Şirin and Necmettin Alkan, Alkan asserted the critics from Şirin on his work as an attack to his personal dignity. For the details of the discussion from the first article to the last, see: Şirin, "Bir Kitabın Düşündürdükleri: Avrupa Karikatürlerinde II. Abdülhamid ve Osmanlı İmajı”, Toplumsal Tarih, vol. 155 (2016), 44-48; Şirin, “Üç Kitap-İki Eleştiri: Necmettin Alkan'ın İlgili Çalışmalarında Yöntem Sorunu Üzerine Eleştiri”, Müteferrika, vol. 57 (2020), 227-233; Necmettin Alkan, “'Yöntemi Olmayan Bir Yöntem Eleştirisi' Olarak İbrahim Şirin Örneği”, Müteferrika, vol. 58 (2020): 261-273; Şirin “Üç Kitap Üç Eleştiri: Yöntemsizliği Yöntem Olarak Savunmak Nasıl Mümkün Olabilir? Necmettin Alkan Örneği”, Academia, accessed April 10, 2021, https://www.academia.edu/45582512.
} 


\section{REFERENCES:}

\section{ARCHIVE DOCUMENTS:}

\section{T.C. Cumhurbaşkanlığı Devlet Arşivleri Başkanlığı, Osmanlı Arşivi (BOA):}

Bab-1 Ali Evrak Odası (BEO)

Dahiliye Hapishaneler Müdiriyeti (DH.MB..HPS.)

Dahiliye İdare (DH.İD.)

Dahiliye İdare-yi Umumiyye (DH.İ.UM)

Dahiliye Muhaberat-1 Umumiye İdaresi (DH.MUi)

Dahiliye Nezareti Mektubi Kalemi (MF.MKT.)

Dahiliye Siyasi Kısım (DH.SYS)

İrade Defteri Hakani (İ..DFE.)

İrade Maarif (İ.MF)

Maarif Nezareti, Tedrisat-1 İbtidaiye Kalemi (MF.İBT.)

Mabeyn-i Hümayun Evrakı İradeleri (MB.İ.)

Satın Alınan Evrak Hacı Adil Bey Evrakı (HSDHADB)

Umur-1 Mahalliye ve Vilayat Müdürlüğ̈̈ (DH.UMVM)

Yıldız Hususi Maruzat (Y..A...HUS.)

Zabtiye (ZB.)

T.C. Cumhurbaşkanlığı Devlet Arşivleri Başkanlığı, Cumhuriyet Arşivi (BCA):

BAŞBAKANLIK, KARARLAR DAİRE BAŞKANLIĞI (1920-1928)

\section{Türk Tarih Kurumu Başkanlığı Mikro Film Arşivi:}

The Papers of Mark Sykes, DDSY2/4 Foreign Affairs and Travel (1888-1919)

\section{PUBLISHED BOOKS AND ARTICLES}

AHMAD, Feroz. Ittihat ve Terakki 1908-1914. Translated by Nuran Yavuz. İstanbul: Kaynak Yayınları, 2019.

AKCAN, Erol. Itttihat ve Terakki Fırkası'nın Paramiliter Gençlik Kuruluşları. Ankara: Türk Tarih Kurumu Yayınları, 2015.

AKŞİN, Sina. Jön Türkler ve İttihat ve Terakki. İstanbul: İmge Kitabevi, 2017.

ALKAN, Necmettin, “'Yöntemi Olmayan Bir Yöntem Eleştirisi’ Olarak İbrahim Şirin Örneği”, Müteferrika, vol.58 (2020): 261-273.

ATATÜRK, Mustafa Kemal. Nutuk, vol.1. İstanbul: Milli Eğitim Basımevi, 1962.

AYDIN, Suavi. “İki İttihat-Terakki: İki Ayrı Zihniyet, İki Ayrı Siyaset”. Modern Türkiye'de Siyasi Düsünce: Cumhuriyet'e Devreden Düşünce Mirası, Tanzimat ve Meşrutiyet'in Birikimi, 117-128. İstanbul: İletişim Yayınları, 2009.

BAYAR, Celal. Ben de Yazım, vol.I. İstanbul: Türkiye İş Bankası Kültür Yayınları, 2018. . Ben de Yazdım, vol.II. İstanbul: Türkiye İş Bankası Kültür Yayınları, 2018. 
. Ben de Yazım, vol.III. İstanbul: Türkiye İş Bankası Kültür Yayınları, 2018.

BAYUR, Yusuf Hikmet. Türk Inkılap Tarihi, vol.I, no. II. Ankara: Türk Tarih Kurumu Basımevi, 1991.

BELGE, Murat. Militarist Modernleşme - Almanya, Japonya ve Türkiye. İstanbul: İletişim Yayınları, 2012.

BİRGEN, Muhittin. Ittihat ve Terakki'de On Sene, edited by Zeki Arıkan. İstanbul: Kitap Yayınevi, 2017.

BİRINCİ, Ali. "Sultan Abdülhamid'in Hâtıra Defteri Meselesi", Dîvân İlmi Araştırmalar, vol.19 (2005): 177-194.

BLEDA, Mithat Şükrü. Imparatorluk Çökerken, edited by Turgut Bleda. İstanbul: Destek Yayınevi, 2010.

Cemal Paşa. Hatıralar, edited by Alpay Kabacalı. İstanbul: Türkiye İş Bankası Yayınları, 2001.

COHEN, I. Bernard, "Analogy, Homology, and Metaphor in the Interactions between the Natural Sciences and the Social Sciences, Especially Economics", History of Political Economy, vol.25, no.1 (1993): 5-44.

ÇİFTÇİ, Ali, “İttihat ve Terakki Cemiyeti’nin Örgütlenme ve Yönetim Yapısı İçinde Kulüplerin Yeri”, Selçuk Üniversitesi Türkiyat Araştırmaları Dergisi, vol.37 (2015): 115-141.

ÇIFTSÜREN, Arzu, "Şibli Numani'nin Seyahatnamesinde II. Abdülhamid ve Gazi Osman Paşa", Doğu Araştırmaları, vol.18 (2018): 5-16.

DERINGIL, Selim. Simgeden Millete - II. Abdülhamid'den Mustafa Kemal'e Devlet ve Millet. İstanbul: İletişim Yayınları, 2009.

DURU, Kazım Nami. Hatıralar: Ittihat ve Terakki/Cumhuriyet Devri/Makedonya Hattralarl, edited by Mustafa Bekmezci. Ankara: Altınordu Yayınları, 2017.

ERDEM, Y. Hakan. Tarih-Lenk. İstanbul: Doğan Kitap, 2017.

ERDINÇ, Erol Şadi. "Giriş", Osmanlı Ittihad ve Terakki Cemiyeti Yargılamaları, vol.I, edited by Erol Şadi Erdinç. İstanbul: Türkiye İş Bankası Kültür Yayınları, 2018.

. "Giriş", Osmanlı İttihad ve Terakki Cemiyeti Yargılamaları, vol.II, edited by Erol Şadi Erdinç. İstanbul: Türkiye İş Bankası Kültür Yayınları, 2018.

GOLOĞLU, Mahmut. Milli Mücadele Tarihi, vol.2. Ankara: Nüve Matbaası, 1968.

GÖÇEK, Fatma Müge \& Murat Özyüksel, "The Ottoman Empire's Negotiation of Western Liberal Imperialism", Liberal Imperializm in Europe, edited by Matthew P. Fitzpatrick, 193-218, New York: Palgrave Macmillan, 2012.

Hatibzade Mehmet Ayetullah. Kime Rey Verelim? Ittihat ve Terakki - Hürriyet ve Itilaf Hangisi İyi. İstanbul: Matbaa-yı Hayriye ve Şürekası, 1328 [1912].

KANTARCI, Şenol, "Ermeni Sorununa Pencereden Bakmak ya da Manzaranın Bütününü Görmek: Taraflar, Tarafsızlar ve Tarafsız Olduklarını Beyan Etme Zorunluluğu Hissederek Taraf Tutanlar mı Var?", OTAM Ankara Üniversitesi Osmanlı Tarihi Araștırma ve Uygulama Merkezi Dergisi, vol.19, no.19 (2006): 199-217.

KARA, İlyas. İttihatçılar Ölür, İttihatçılık Ölmez. İstanbul: Kamer Yayınları, 2020. 
KERIMOĞLU, Hasan Taner. Osmanlı'da Devrim ve Fedakâran-ı Millet - İstibdat Dönemi Sürgün ve Firarilerinin Devr-i Hürriyet'te Mücadeleleri. İstanbul: Tarih Vakfı Yurt Yayınlar1, 2018.

KÜÇÜKKILINÇ, İsmail. Jön Türklük ve Kemalizm Kıskacında İttihadçılık. İstanbul: Historia Kitap, 2018.

KÜÇÜKÖMER, İdris. “Batılaşma” Düzenin Yabancılaşması. İstanbul: Bağlam Yayınları, 1994.

LERMIOĞLU, Osman Nuri. Halkın İstemediği İnkılap - Meşrutiyet. İstanbul: Sabah Kültür Yayınları, 1976.

LEWIS, Bernard. The Emergence of Modern Turkey. Oxford: Oxford University Press, 1961.

Mehmed Selahaddin Bey. Ittihad ve Terakki'nin Kuruluşu ve Osmanlı Devleti'nin Yıkılışı Hakkında Bildiklerim, edited by Ahmed Varol. İstanbul: İnkılab Yayınları, 2017.

Mehmed Talat Paşa. Hatıralarım ve Müdafaam, edited by Atatürk'ün Bütün Eserleri Çalışma Grubu. İstanbul: Kaynak Yayınları, 2006.

Mehmed Talat Paşa. Talât Paşa'nın Anıları, edited by Alpay Kabacalı. İstanbul: Türkiye İş Bankası Yayınları, 2000.

NEYYAL, Naciye. Ressam Naciye Neyyal'in Mutlakiyet, Meşrutiyet ve Cumhuriyet Hatıralarl, edited by Fatma Rezzan Hürmen. İstanbul: Pınar Yayınları, 2000.

ODABAȘ, İ. Arda. "İttihat ve Terakki Cemiyeti Süleymaniye Kulübü'nün Anadolu Köylüsü İçin Çıkardığı Bir Yayın: Işık”, İstanbul Arel Üniversitesi İletişim Çalışmaları Dergisi, vol.4, no.7 (2015): 13-31.

“'Selanik İttihat ve Terakki Üçüncü Kulübü’nün Köylü / Köycü Gazetesi: Vatandaş", Çağdaş Türkiye Tarihi Araştırmaları Dergisi, vol.10, no.22 (2011): 47-63.

ORBAY, Rauf. Cehennem Değirmeni - Siyasi Hatıralarım, vol.2. İstanbul: Emre Yayınları, 1993.

Osmanl Ittihad ve Terakki Cemiyeti Program ve Nizamnamesidir - 1332 Senesi Umumi Kongresinde Tadil ve Kabul Edilmiştir. İstanbul: Tanin Matbaası, 1332 [1916].

ÖZEL, Oktay. Dün Sancısı - Türkiye'de Geçmiş Algısı ve Akademik Tarihçilik, İstanbul: Tarih Vakf1 Yurt Yayınları, 2012.

ÖZTÜRK, Oğuzhan Murat. "Dönem Hatıratları Işı̆̆ında İttihat ve Terakki ve İttihatçılar”. İttihat ve Terakki Cemiyeti - Vatan Namus Ittihad, edited by Hakan Boz, 231-254. İstanbul: Historia Yayınları, 2018.

SIRMA, İhsan Süreyya. II. Abdülhamid'in İslam Birliği Siyaseti. İstanbul: Beyan Yayınları, 1989.

SOKU, Ziya Şakir. İttihat ve Terakki Nasıl Doğdu?. İstanbul: Akıl Fikir Yayınları, 2018. Ittihat ve Terakki Nasıl Öldü?. İstanbul: Akı1 Fikir Yayınları, 2018. Itttihat ve Terakki Nasıl Yaşadı?. İstanbul: Akıl Fikir Yayınları, 2018. Paşalar - Talat-Enver-Cemal. İstanbul: Kaknüs Yayınları, 2010.

SÜRURI, Ali Nazif. Son Firsat. İstanbul: Keteon Matbaas1, 1334 [1918].

ŞİMŞEK, Muttalip. "Osmanlı Devleti'nde Türkçe'nin Gayrimüslim Okullarında Mecburi Hale Getirilmesi ve Uygulanması", OTAM Ankara Üniversitesi Osmanlı Tarihi Araştırma ve Uygulama Merkezi Dergisi, vol.43 (2018): 199-227. 
ŞİMŞíRGíl, Ahmet. Kayı - Osmanlı Tarihi X, II. Abdülhamid Han. İstanbul: Timaş Yayınları, 2018.

ŞİRIN, İbrahim. "Bir Kitabın Düşündürdükleri: Avrupa Karikatürlerinde II. Abdülhamid ve Osmanlı İmaj1”, Toplumsal Tarih, vol.155 (2016): 44-48.

“Türkiye'de İttihatçılık Algısı ve İttihat ve Terakki Çalışmaları". Türkiye'den Aydın Portreleri: Kurtuluş Kayalı, ed. Aytaç Yıldız, 264-265. İstanbul: Doğu Batı Yayınlar1, 2018.

“Üç Kitap-İki Eleştiri: Necmettin Alkan'ın İlgili Çalışmalarında Yöntem Sorunu Üzerine Eleştiri”, Müteferrika, vol.57, (2020): 227-233.

“Üç Kitap Üç Eleştiri: Yöntemsizliği Yöntem Olarak Savunmak Nasıl Mümkün Olabilir? Necmettin Alkan Örneği”. Academia. Accessed April 10, 2021. https://www.academia.edu/45582512.

TOPRAK, Zafer. "Bir Hayal Ürünü: İttihatçıların 'Türkleştirme Politikası"”, Toplumsal Tarih, vol.146, (2006): 14-22.

Türkiye'de Milli İktisat 1908-1918. İstanbul: Doğan Kitap, 2012.

TUNAYA, Tarık Zafer. Türkiye'de Siyasal Partiler, vol.I. İstanbul: Hürriyet Vakfı Yurt Yayınları, 1988.

Yayınlar1, 1986.

Türkiye'de Siyasal Partiler, vol.II. İstanbul: Hürriyet Vakfi Yurt

Yayınları, 1989.

Türkiye'de Siyasal Partiler, vol.III. İstanbul: Hürriyet Vakfi Yurt

US, Asım. Gördüklerim, Duyduklarım, Duygularım - Meşrutiyet ve Cumhuriyet Devirlerine Ait Hatıralar ve Tetkikler. İstanbul: Vakit Matbaas1, 1964.

USLU, Kaan \& Yavuz Büyüktuncay, ed. Osmanlı İmparatorluğu Madeni Paraları 1839-1922 (AH 1255-1340). İstanbul: Osmanlı Nümismatik Kültür Yayınları, 2018.

VURUCU, İkbal. "Yeni Türkiye'de Tarih Savaşları", Bayrak Kalpak Revolver - Itttihat ve Terakki Cemiyeti, ed. Hakan Boz, 332-349. Ankara: İhtimal Dergisi Yayınevi, 2016.

YALÇIN, Hüseyin Cahit. Siyasal Anılar. İstanbul: Türkiye İş Bankası Kültür Yayınları, 2000.

YAZICİ, Serkan. "Sultan II. Abdülhamid Örneğinde Tarihsel Algılamanın Değişimi”, History Studies International Journal of History, vol. 6, no. 5 (September 2014): 233-247.

YILMAZ, H. Raşit. "İmparatorluğa Veda Arifesinde Bir Nesil: İttihatçılar - 1908-1913 Cemiyetin Varoluş Mücadelesi”. Bayrak Kalpak Revolver - İtihat ve Terakki Cemiyeti, ed. Hakan Boz, 23-35, Ankara: İhtimal Dergisi Yayınevi, 2016.

ZURCHER, Erik Jan. "Young Turk Governance in the Ottoman Empire during the First World War", Middle Eastern Studies, vol.56, no.6, (2019): 897-913.

Millî Mücadelede İttihatçılık. Translated by Nüzhet Salihoğlu, İstanbul: İletişim Yayınları, 2016.

Modernleşen Türkiye'nin Tarihi. Translated by Yasemin Saner Gönen, İstanbul: İletişim Yayınları, 2000. 


\section{Unpublished Thesis and Dissertations}

AYDIN, Hakan. İtihat ve Terakki Mekteplerinin Yapısal Özellikleri Üzerine Bir İnceleme. PhD diss., Konya: Selçuk University, 2008.

KAZANCI, Onur. Bir Yıkıcı Liderlik Örneği: Sultan II. Abdülhamid. PhD diss., İzmir: Ege University, 2019.

SERGIN, İsa. Cumhuriyet ve Cumhuriyet Öncesi Türk Aydınlarının Hatıratlarında Sultan II. Abdülhamit Imgesi, Master's Thesis, İstanbul: İstanbul Sabahattin Zaim University, 2020.

YABAN, Nesli Tuğban. İtalya Basınında Sultan II. Abdülhamid Dönemi Osmanlı İmgesi. PhD diss., Ankara: Hacettepe University, 2018. 